\title{
EVALUATION OF SOME FERMENTED MILKS SOLD IN ALEXANDRIA CITY
}

\author{
AHLAM, A. EL LEBOUDY*; AMR, A. AMER*; MARIA, A. EL-ANSARY**; \\ EL ASUOTY, M.S*** and MARWA, R. AHMIDA**** \\ * Professor of Milk Hygiene, Department of Food Hygiene, Fac. Vet. Med. Alexandria. Univ. \\ ** Lecturer of Milk Hygiene, Department of Food Hygiene, Fac. Vet. Med. Alexandria. Univ. \\ *** Researcher of Food Hygiene Unit, Animal Health Research Institute, Damanhur branch. \\ **** Researcher at Department of Food Hygiene, Fac, of Vet, Med, Alexandria, Univ.
}

Received: 31 May 2017; $\quad$ Accepted: 25 July 2017

\begin{abstract}
One hundred and twenty random samples of some locally manufactured fermented dairy products including; plain yoghurt, stirred yoghurt, flavored yoghurt, baladi rayeb, sterilized rayeb and Labnah (20 each) were collected from local markets in Alexandria city to be examined for their sanitary and microbiological evaluation. The obtained results clarified that the mean value of the titratable acidity was $0.83 \pm 0.007,0.65 \pm 0.01$, $0.68 \pm 0.011,0.89 \pm 0.005,0.66 \pm 0.01$ and $0.14 \pm 0.08 \%$, respectively. In addition, the mean value of coliforms count cfu/g was $4.10 \times 10^{2} \pm 20 ;<10 ; 1.72 \times 10^{2} \pm 21 ; 1.65 \times 10^{3} \pm 2.69 \times 10^{2} ;<10$ and $6.10 \times 10^{2} \pm 64$, respectively. The isolated coliforms species were Citrobacter freundii, E.coli, Enterobacter aerogenes, Enterobacter cloacae, Proteus vulgaris, Edwardsiella tarda and Klebsiella pneumoniae. None of them was isolated from stirred yoghurt and sterilized rayeb. The mean value of Staph. aureus count cfu/g was $22 \pm 5 ; 20 \pm 10 ; 64 \pm 45$; $7.23 \times 10^{2} \pm 54 ; 2.1 \times 10^{2} \pm 21$ and $95 \pm 12$, respectively. The mean value of Enterococci count cfu/g was $1.25 \times 10^{2} \pm$ $12 ; 1.25 \times 10^{2} \pm 23.2 ; 1.21 \times 10^{2} \pm 11 ; 4.25 \times 10^{2} \pm 1.97 \times 10^{2} ; 22.5 \pm 13$ and $1.66 \times 10^{3} \pm 6.6 \times 10^{2}$, respectively. Moreover, the yeasts and molds counts were performed. The mean value of yeasts count cfu/g was $7.87 \times 10^{4} \pm$ $6.89 \times 10^{4} ; 5.83 \times 10^{3} \pm 3.68 \times 10^{3} ; 2.16 \times 10^{3} \pm 6.54 \times 10^{2} ; 1.26 \times 10^{4} \pm 3.55 \times 10^{3} ; 9.11 \times 10^{3} \pm 3.82 \times 10^{3}$ and $1.28 \times 10^{3} \pm$ $0.79 \times 10^{2}$, respectively. While the mean value of molds count cfu/g was $5.88 \times 10^{4} \pm 4.06 \times 10^{4}$; $2.60 \times 10^{3} \pm 1.12 \times 10^{3} ; 7.57 \times 10^{3} \pm 4.72 \times 10^{3} ; 2.92 \times 10^{3} \pm 4.38 \times 10^{2} ; 3.00 \times 10^{3} \pm 1.41 \times 10^{3}$ and $2.75 \times 10^{3} \pm 1.12 \times 10^{3}$, respectively. It could be concluded that the majority of the investigated fermented dairy products were contaminated, at different degrees, with coliforms, Staph. aureus, yeasts and molds giving an indication of poor sanitary measures adopted during manufacturing, storage, handling and distribution of these products. In addition, it was observed that baladi rayeb and Labnah had lower quality than the other examined fermented dairy products.
\end{abstract}

Key words: Fermented dairy products, Sanitary Evaluation, Microbiological Evaluation.

\section{INTRODUCTION}

The consumption of fermented milks by man dates from the beginning of civilization, once residues of these products were found in pottery fragments from Neolithic Bronze and iron ages settlements in Britain (Mckinley, 2005). Fermented milk products are dairy foods that have been fermented with lactic acid bacteria such as Lactobacillus, Lactococcus and Leuconostoc. The fermentation process increases the shelf-life of the product, while enhancing the taste and improving the digestibility of milk. Various types of fermented

Corresponding author: Dr. AHLAM, A. EL LEBOUDY

E-mail address:mido_15158@hotmail.com

Present address: Professor of Milk Hygiene, Department of Food Hygiene, Fac. Vet. Med. Alexandria. Univ. milks and derived products have been developed in all parts of the world, each with its own characteristic history. Their nature depends very much on the type of milk used, on the pre-treatment of the milk, on the temperature (climate) and the conditions of fermentation and on the subsequent technological treatments (Tamine and Robison, 2007).

The most common traditional fermented milks are yoghurt, stirred baladi rayeb, sterilized rayeb and Labnah. Yoghurt is a popular fermented milk product consumed in many parts of the world. It is produced in different forms such as whole milk yoghurt, skim milk yoghurt, cream yoghurt, fruit yoghurt and liquid stirred yoghurt (Balasubramanyam and Kulkarni, 1991). It is an extremely popular fermented milk too in Europe, Asia and Africa (Thapa, 2000). Moreover, yoghurt is recommended for sick and convalescent people. Also, it inhibits the bacterial flora of intestine 
which may lead to constipation, autointoxication and colitis as well as it helps the absorption of calcium and phosphorus (Khan et al., 2008).

Dairy fermented products are liable to contamination with different types of microorganisms from different sources during production, processing and handling, which lead them to be unfit for consumption and constitute a public health hazard (Todaro et al., 2013). Coliforms are routinely used as an indicator to evaluate the quality of milk and milk products as some members of coliforms are responsible for the development of objectionable taints in milk and its products rendering them of inferior quality or even unmarketable (Yabaya and Idris, 2012). Staphylococcus aureus (Staph. aureus) in food article is considered as an index of contamination from personnel sharing in production and handling .Moreover, Staph. aureus is capable of producing several enterotoxins that when ingested through contaminated food could cause food poisoning in human with varying intensity (Brightwell et al., 2006). Enterococcus organisms have a distinctive role as an indicator of poor factory sanitation owing to their relatively high resistance to drying, detergents, as well as freezing temperature. Moreover, these organisms are also implicated in food poisoning outbreaks (Yabaya and Idris, 2012). Fungi usually contaminate fermented dairy products during processing, storage and distribution (Pitt and Hocking, 2009). Yeast is a major cause of yogurt spoilage and other fermented milks in which the low $\mathrm{pH}$ provides a selective environment for their growth (Fleet, 1990). Poor hygiene, practiced by handlers of fermented milk products in local markets, may lead to spoilage with pathogenic microorganisms (Tamine and Robison, 2007).

To ensure the safety and quality of fermented milk products consumed at local markets, they must be evaluated by sanitary and microbiological quality and matching with the Egyptian Standards. Therefore, The present study was designed to evaluate some fermented milk products including; plain yoghurt, stirred yoghurt, flavored yoghurt, baladi rayeb, sterilized rayeb and Labnah.

\section{MATERIALS AND METHODS}

\section{Collection of samples:}

A total of one hundred and twenty (120) random samples of locally manufactured fermented milk in the form of plain yoghurt, stirred yoghurt, flavored yoghurt, baladi rayeb, sterilized rayeb and Labnah (20 each) were collected from groceries and supermarkets from various localities in Alexandria city. The collected samples were obtained in their containers as sold to the public or in sterile cups. The samples were dispatched directly to the laboratory of Food Hygiene Department with a minimum of delay in an ice box where they prepared and examined for sanitary and microbiological examination.

\section{Methods:}

2.1. Determination of titratable acidity of fermented milk samples (AOAC, 1990).

2.2. Microbiological evaluation of the examined prepared samples:

2.2.1. Preparation of fermented milk samples according to (APHA, 1985).

2.2.2. Coliforms count was determined using plate method onto plates of violet red bile agar (Difco) according to the method reported by FDA (2002).

2.2.3. Staphylococcus aureus count (Baird-Parker, 1962).

2.2.4. Enumeration of Enterococci (Deibel and Hartman, 1982).

2.2.5. Isolation and counting of yeasts and molds (Baily and Scott, 1998).

2.3. The obtained results were statistically analyzed by "ANOVA" that was conducting using SAS software (SAS, 2014).

\section{RESULTS}

Table 1: Statistical analytical results of titratable acidity percent of the examined fermented dairy products (20 each).

\begin{tabular}{cccc}
\hline \multirow{2}{*}{ Fermented dairy products } & \multicolumn{3}{c}{ Titratable acidity \% } \\
\cline { 2 - 4 } & Minimum & Maximum & Mean \pm SEM \\
\hline Plain yoghurt & 0.79 & 0.89 & $0.83 \pm 0.007$ \\
\hline Stirred yoghurt & 0.59 & 0.78 & $0.65 \pm 0.01$ \\
\hline Flavored yoghurt & 0.59 & 0.78 & $0.68 \pm 0.011$ \\
\hline Baladi rayeb & 0.85 & 0.93 & $0.89 \pm 0.005$ \\
\hline Sterilized rayeb & 0.59 & 0.78 & $0.66 \pm 0.01$ \\
\hline Labnah & 0.10 & 2.40 & $0.14 \pm 0.08$ \\
\hline
\end{tabular}


Table 2: Statistical analytical results of coliforms count of the examined fermented dairy products samples (20 each).

\begin{tabular}{cccccc}
\hline Fermented dairy products & \multicolumn{2}{c}{ Positive samples } & \multicolumn{3}{c}{ count (cfu/ g) } \\
\cline { 2 - 6 } & No. & $\%$ & Minimum & Maximum & Mean \pm SEM \\
\hline Plain yoghurt & 10 & 50 & $3.10 \times 10^{2}$ & $5.10 \times 10^{2}$ & $4.10 \times 10^{2} \pm 20$ \\
\hline Stirred yoghurt & $0^{*}$ & 0.0 & $<10$ & $<10$ & $<10$ \\
\hline Flavored yoghurt & 5 & 25 & $1.10 \times 10^{2}$ & $2.30 \times 10^{2}$ & $1.72 \times 10^{2} \pm 21$ \\
\hline Baladi rayeb & 20 & 100 & $1.00 \times 10^{3}$ & $3.50 \times 10^{3}$ & $1.65 \times 10^{3} \pm 2.69 \times 10^{2}$ \\
\hline Sterilized rayeb & $0^{*}$ & 0.0 & $<10$ & $<10$ & $<10$ \\
\hline Labnah & 20 & 100 & $1.00 \times 10^{2}$ & $1.20 \times 10^{3}$ & $6.10 \times 10^{2} \pm 64$ \\
\hline
\end{tabular}

*no colonies could be detected on the plates.

Table 3: Incidence $\%$ of coliforms isolated from the examined yoghurt samples (20 each).

\begin{tabular}{ccccccc}
\hline \multirow{2}{*}{ isolates } & \multicolumn{2}{c}{ Plain yoghurt } & \multicolumn{2}{c}{ Stirred yoghurt } & \multicolumn{2}{c}{ Flavored yoghurt } \\
\cline { 2 - 7 } & No. & $\%$ & No. & $\%$ & No. & $\%$ \\
\hline Citrobacter freundii & 4 & 20.0 & 0 & 0.0 & 3 & 15.0 \\
\hline E. coli & 5 & 25.0 & 0 & 0.0 & 3 & 15.0 \\
\hline Edwardsiella tarda & 4 & 20.0 & 0 & 0.0 & 0 & 00.0 \\
\hline Enterobacter aerogens & 6 & 30.0 & 0 & 0.0 & 3 & 15.0 \\
\hline Enterobacter cloacae & 6 & 30.0 & 0 & 0.0 & 3 & 15.0 \\
\hline Klebsiella pneumoniae & 4 & 20.0 & 0 & 0.0 & 0 & 0.0 \\
\hline Proteus vulgaris & 4 & 20.0 & 0 & 0.0 & 3 & 15.0 \\
\hline
\end{tabular}

Table 4: Incidence of coliforms isolated from the examined rayeb samples (20 each).

\begin{tabular}{ccccccc}
\hline \multirow{2}{*}{ isolates } & \multicolumn{2}{c}{ Baladi rayeb } & \multicolumn{2}{c}{ Sterilized rayeb } & \multicolumn{2}{c}{ Labnah } \\
\cline { 2 - 7 } & No. & $\%$ & No. & $\%$ & No. & $\%$ \\
\hline Citrobacter freundii & 5 & 25.0 & 0 & 0.0 & 6 & 30.0 \\
\hline E. coli & 6 & 30.0 & 0 & 0.0 & 6 & 30.0 \\
\hline Edwardsiella tarda & 8 & 40.0 & 0 & 0.0 & 6 & 30.0 \\
\hline Enterobacter cloacae & 3 & 15.0 & 0 & 0.0 & 3 & 15.0 \\
\hline Klebsiella pneumoniae & 7 & 35.0 & 0 & 0.0 & 6 & 30.0 \\
\hline Proteus vulgaris & 6 & 30.0 & 0 & 0.0 & 6 & 30.0 \\
\hline
\end{tabular}

Table 5: Statistical analytical results of Staph. aureus count of the examined fermented dairy products (20 each).

\begin{tabular}{cccccc}
\hline \multirow{2}{*}{ Fermented dairy products } & \multicolumn{2}{c}{ Positive samples } & \multicolumn{3}{c}{ count $(\mathbf{c f u} / \mathbf{g})$} \\
\cline { 2 - 6 } & No. & $\%$ & Minimum & Maximum & Mean \pm SEM \\
\hline Plain yoghurt & 2 & 10.0 & 10 & 40 & $22 \pm 5$ \\
\hline Stirred yoghurt & 4 & 20.0 & 10 & 50 & $20 \pm 10$ \\
\hline Flavored yoghurt & 7 & 35.0 & 10 & $3.3 \times 10^{2}$ & $64 \pm 45$ \\
\hline Baladi rayeb & 17 & 85.0 & $1.50 \times 10^{2}$ & $9.90 \times 10^{2}$ & $7.23 \times 10^{2} \pm 54$ \\
\hline Sterilized rayeb & 8 & 40.0 & $2.1 \times 10^{2}$ & $4.0 \times 10^{2}$ & $2.1 \times 10^{2} \pm 21$ \\
\hline Labnah & 20 & 100.0 & 13 & $2.40 \times 10^{2}$ & $95 \pm 12$ \\
\hline
\end{tabular}


Table 6: Statistical analytical results of Enterococci count of the examined fermented dairy products (20 each).

\begin{tabular}{cccccc}
\hline \multirow{2}{*}{ Fermented dairy products } & \multicolumn{2}{c}{ Positive samples } & \multicolumn{3}{c}{ count $(\mathbf{c f u} / \mathbf{g})$} \\
\cline { 2 - 6 } & No. & $\%$ & Minimum & Maximum & Mean \pm SEM \\
\hline Plain yoghurt & 2 & 10.0 & 10 & $3.00 \times 10^{2}$ & $1.25 \times 10^{2} \pm 12$ \\
\hline Stirred yoghurt & 5 & 25.0 & 20 & $2.50 \times 10^{2}$ & $1.25 \times 10^{2} \pm 23.2$ \\
\hline Flavored yoghurt & 3 & 15.0 & 50 & $2.00 \times 10^{2}$ & $1.21 \times 10^{2} \pm 11$ \\
\hline Baladi rayeb & 4 & 20.0 & $1.00 \times 10^{2}$ & $1.00 \times 10^{3}$ & $4.25 \times 10^{2} \pm 1.97 \times 10^{2}$ \\
\hline Sterilized rayeb & 1 & 5.0 & 10 & 70 & $22.5 \pm 13$ \\
\hline Labnah & 3 & 15.0 & $1.00 \times 10^{3}$ & $3.00 \times 10^{3}$ & $1.66 \times 10^{3} \pm 6.6 \times 10^{2}$ \\
\hline
\end{tabular}

Table 7: Statistical analytical results of yeasts count of the examined fermented dairy products (20 each).

\begin{tabular}{cccccc}
\hline \multirow{2}{*}{ Fermented dairy products } & \multicolumn{2}{c}{ Positive samples } & \multicolumn{3}{c}{ count $(\mathbf{c f u} / \mathbf{g})$} \\
\cline { 2 - 6 } & No. & $\%$ & Minimum & Maximum & Mean \pm SEM \\
\hline Plain yoghurt & 14 & 70.0 & $1.00 \times 10^{3}$ & $9.70 \times 10^{5}$ & $7.87 \times 10^{4} \pm 6.89 \times 10^{4}$ \\
\hline Stirred yoghurt & 6 & 30.0 & $1.00 \times 10^{3}$ & $2.40 \times 10^{4}$ & $5.83 \times 10^{3} \pm 3.68 \times 10^{3}$ \\
\hline Flavored yoghurt & 6 & 30.0 & $1.00 \times 10^{3}$ & $5.00 \times 10^{3}$ & $2.16 \times 10^{3} \pm 6.54 \times 10^{2}$ \\
\hline Baladi rayeb & 11 & 55.0 & $2.00 \times 10^{3}$ & $3.80 \times 10^{4}$ & $1.26 \times 10^{4} \pm 3.55 \times 10^{3}$ \\
\hline Sterilized rayeb & 9 & 45.0 & $1.00 \times 10^{3}$ & $3.50 \times 10^{4}$ & $9.11 \times 10^{3} \pm 3.82 \times 10^{3}$ \\
\hline Labnah & 7 & 35.0 & $1.00 \times 10^{3}$ & $1.40 \times 10^{3}$ & $1.28 \times 10^{3} \pm 0.79 \times 10^{2}$ \\
\hline
\end{tabular}

Table 8: Statistical analytical results of molds count of the examined fermented dairy products (20 each).

\begin{tabular}{cccccc}
\hline \multirow{2}{*}{ Fermented dairy products } & \multicolumn{2}{c}{ Positive samples } & \multicolumn{3}{c}{ count $(\mathbf{c f u} / \mathbf{g})$} \\
\cline { 2 - 6 } & No. & $\%$ & Minimum & Maximum & Mean \pm SEM \\
\hline Plain yoghurt & 11 & 55.0 & $1.00 \times 10^{3}$ & $4.40 \times 10^{5}$ & $5.88 \times 10^{4} \pm 4.06 \times 10^{4}$ \\
\hline Stirred yoghurt & 5 & 25.0 & $1.00 \times 10^{3}$ & $7.00 \times 10^{3}$ & $2.60 \times 10^{3} \pm 1.12 \times 10^{3}$ \\
\hline Flavored yoghurt & 7 & 35.0 & $1.00 \times 10^{3}$ & $3.50 \times 10^{4}$ & $7.57 \times 10^{3} \pm 4.72 \times 10^{3}$ \\
\hline Baladi rayeb & 14 & 70.0 & $1.00 \times 10^{3}$ & $5.00 \times 10^{3}$ & $2.92 \times 10^{3} \pm 4.38 \times 10^{2}$ \\
\hline Sterilized rayeb & 4 & 20.0 & $1.00 \times 10^{3}$ & $7.00 \times 10^{3}$ & $3.00 \times 10^{3} \pm 1.41 \times 10^{3}$ \\
\hline Labnah & 20 & 100.0 & $2.00 \times 10^{3}$ & $3.5 \times 10^{3}$ & $2.75 \times 10^{3} \pm 1.12 \times 10^{3}$ \\
\hline
\end{tabular}

Table 9: Comparison of the obtained results of microbiological evaluation of the examined yoghurt samples with the Egyptian standards (1999) and EOSQC (2005).

\begin{tabular}{|c|c|c|c|c|c|c|c|c|c|c|c|c|c|}
\hline \multirow{3}{*}{ Count (CFU/g) } & \multirow{3}{*}{$\begin{array}{l}\text { Egyptian } \\
\text { Standards }\end{array}$} & \multicolumn{4}{|c|}{$\begin{array}{l}\text { Plain yoghurt } \\
\quad(\mathbf{n}=\mathbf{2 0})\end{array}$} & \multicolumn{4}{|c|}{$\begin{array}{l}\text { Stirred yoghurt } \\
\qquad(\mathrm{n}=\mathbf{2 0})\end{array}$} & \multicolumn{4}{|c|}{$\begin{array}{l}\text { Flavored yoghurt } \\
\qquad(\mathbf{n}=\mathbf{2 0})\end{array}$} \\
\hline & & \multicolumn{2}{|c|}{ Within* } & \multicolumn{2}{|c|}{ Fail** } & \multicolumn{2}{|c|}{ Within* } & \multicolumn{2}{|c|}{ Fail** } & \multicolumn{2}{|c|}{ Within* } & \multicolumn{2}{|c|}{ Fail $^{* *}$} \\
\hline & & No. & $\%$ & No. & $\%$ & No. & $\%$ & No. & $\%$ & No. & $\%$ & No. & $\%$ \\
\hline Coliforms count & $<10(\mathrm{cfu} / \mathrm{g})$ & 10 & 50 & 10 & 50 & 20 & 100 & 0 & 0.0 & 15 & 75 & 5 & 25 \\
\hline Staph. aureus count & Nil & 18 & 90 & 2 & 10 & 16 & 80 & 4 & 20 & 13 & 65 & 7 & 35 \\
\hline Yeasts count & (1999) Nil & 6 & 30 & 14 & 70 & 14 & 70 & 6 & 30 & 14 & 70 & 6 & 30 \\
\hline Molds count & $<10(\mathrm{cfu} / \mathrm{g})$ & 9 & 45 & 11 & 55 & 15 & 75 & 5 & 25 & 13 & 65 & 7 & 35 \\
\hline
\end{tabular}

*Within: means that the examined samples were within the permissible limit of the Egyptian standards.

**Fail: means that the examined samples failed to conform the Egyptian standards 
Table 10: Comparison of the obtained results of microbiological evaluation of the examined Rayeb samples with the Egyptian standards (1999) and EOSQC (2005).

\begin{tabular}{|c|c|c|c|c|c|c|c|c|c|c|c|c|c|}
\hline \multirow{3}{*}{ Count (CFU/g) } & \multirow{3}{*}{$\begin{array}{l}\text { Egyptian } \\
\text { Standards }\end{array}$} & \multicolumn{4}{|c|}{$\begin{array}{l}\text { Baladi rayeb } \\
\qquad(\mathrm{n}=\mathbf{2 0})\end{array}$} & \multicolumn{4}{|c|}{$\begin{array}{l}\text { Sterilized rayeb } \\
\qquad(\mathbf{n}=\mathbf{2 0})\end{array}$} & \multicolumn{4}{|c|}{$\begin{array}{c}\text { Labnah } \\
(n=20)\end{array}$} \\
\hline & & \multicolumn{2}{|c|}{ Within* } & \multicolumn{2}{|c|}{ Fail** } & \multicolumn{2}{|c|}{ Within* } & \multicolumn{2}{|c|}{ Fail $* *$} & \multicolumn{2}{|c|}{ Within* } & \multicolumn{2}{|c|}{ Fail $* *$} \\
\hline & & No. & $\%$ & No. & $\%$ & No. & $\%$ & No. & $\%$ & No. & $\%$ & No. & $\%$ \\
\hline Coliforms count & $<10(\mathrm{cfu} / \mathrm{g})$ & 0 & 0.0 & 20 & 100 & 20 & 100 & 0 & 0.0 & 0 & 0.0 & 20 & 100 \\
\hline Staph. aureus count & Nil & 3 & 15 & 17 & 85 & 12 & 60 & 8 & 40 & 0 & 0.0 & 20 & 100 \\
\hline Yeasts count & (1999) Nil & 9 & 45 & 11 & 55 & 11 & 55 & 9 & 45 & 13 & 65 & 7 & 35 \\
\hline Molds count & $<10(\mathrm{cfu} / \mathrm{g})$ & 6 & 30 & 14 & 70 & 16 & 80 & 4 & 20 & 0 & 0.0 & 20 & 100 \\
\hline
\end{tabular}

*Within: means that the examined samples were within the permissible limit of the Egyptian standards.

**Fail: means that the examined samples fail to conform the Egyptian standards.

\section{DISCUSSION}

\section{Sanitary evaluation of the examined fermented dairy products:}

\subsection{Titratable acidity $\%$ :}

The obtained results recorded in Table 1 clarified that the statistical analysis showed that the mean value of the titratable acidity of the examined samples of the fermented milk products under investigation was $0.83 \pm 0.007, \quad 0.65 \pm 0.01, \quad 0.68 \pm 0.011, \quad 0.89 \pm 0.005$, $0.66 \pm 0.01$ and $0.14 \pm 0.08 \%$, for plain yoghurt, stirred yoghurt, flavored yoghurt, baladi rayeb, sterilized rayeb and Labnah, respectively. On the other hand higher results were detected by Uzeh et al. (2006) who reported that the total titratable acidity in traditional fermented milk in Nigeria "Nano" was $1.37 \%$.

\section{Microbiological evaluation of the examined fermented dairy products:}

\subsection{Coliforms count:}

The presented data in Table 2 showed that coliforms bacteria were detected at an incidence of $50 ; 0.0 ; 25$; $100 ; 0.0$ and $100 \%$, respectively and the mean value of the coliforms count was $4.10 \times 10^{2} \pm 20$; <10 ; $1.72 \times 10^{2} \pm 21 ; 1.65 \times 10^{3} \pm 2.69 \times 10^{2} ;<10$ and $6.10 \times 10^{2} \pm 64 \mathrm{CFU} / \mathrm{g}$, respectively. The recorded results were in agreement with that of Abdel All and Dardir (2009), El-Malt et al. (2013), El-Leboudy et al. (2015), Samet-Bali et al. (2016).

According to the limits proposed by the Egyptian standards (coliforms must be $<10 \mathrm{cfu} / \mathrm{g}$ ), it was noticed that 50 and $25 \%$ of the examined samples of the plain and flavored yoghurt, respectively. Failed to comply with the limit (Table 9), and all of the examined samples of baladi rayeb and Labnah failed to comply with the limits (Table 10). While all the examined stirred yoghurt and sterilized rayeb were comply with the limits (Tables 9 and 10).
Higher coliforms count that observed in this study may be attributed to initial contamination of raw milk either from cows, milkers, milk containers and milking environment. In addition, the high number of coliforms in fermented milk provides an index of hygienic standard used in production of milk, as unclean udder and teats can contribute the presence of coliforms from avariety of sources as manure, soil, food, personal and even water (Yabaya and Idris, 2012). Also, Somer and Kilic (2012) noticed that all the yoghurts that were contaminated with coliforms at levels above the acceptable limits, indicating insufficient hygiene process.

\subsection{Staphylococcus aureus count:}

It was clear from the findings in Table 5 that Staph. aureus were detected at an incidence of 10, 20,35, 85,40 and $100 \%$ in the examined samples, respectively. The mean value of Staph. aureus count in the examined fermented samples was $22 \pm 5 ; 20 \pm$ $10 ; 64 \pm 45 ; 7.23 \times 10^{2} \pm 54 ; 2.1 \times 10^{2} \pm 21$ and $95 \pm 12$ $\mathrm{CFU} / \mathrm{g}$, respectively. These results were in harmony with that reported by Abdel All and Dardir (2009) who found that the mean Staph. aureus count was $478.2 \pm 130 \mathrm{CFU} / \mathrm{g}$. Moreover, El-Leboudy et al. (2015) recorded that the incidence of Staph. aureus was $40 \%$ with a mean count value of $92 \pm 29 \mathrm{CFU} / \mathrm{g}$ in the examined samples of plain yoghurt.

According to the limits proposed by the Egyptian standards (Staph. aureus must not be detected), it was noticed that 10, 20 and $35 \%$ of the examined samples of plain, stirred and flavored yoghurt, respectively failed to comply with the standard limits (Table 9), moreover, 85,40 and $100 \%$ of the examined samples of baladi rayeb, sterilized rayeb and Labnah, respectively failed to comply with the limits (Table 10). The relatively low counts of Staph. aureus in the examined yoghurt samples may be attributed to the action of yoghurt culture, as it was found that the yoghurt culture reduces the concentration of Staph. 
aureus added to milk by 1-2 log units during the cold storage of yoghurt (Pazakova et al., 1997).

\subsection{Enterococci count:}

The data presented in Table 6 clarified that Enterococci were detected at an incidence of 10, 25, $15,20,5$ and $15 \%$ in the examined samples, respectively. The mean value of Enterococci count $\mathrm{cfu} / \mathrm{g}$ was $1.25 \times 10^{2} \pm 12 ; 1.25 \times 10^{2} \pm 23.2 ; 1.21 \times 10^{2} \pm$ $11 ; 4.25 \times 10^{2} \pm 1.97 \times 10^{2} ; 22.5 \pm 13$ and $1.66 \times 10^{3} \pm$ $6.6 \times 10^{2}$, respectively. This result disagreed with those reported with El-Malt et al. (2013). In addition, ElLeboudy et al. (2015) recorded an incidence of $60 \%$ Enterococci organisms with a mean count of 99.9 $\pm 19.4 \mathrm{CFU} / \mathrm{g}$ in the examined samples of plain yoghurt.

\subsection{Yeasts count:}

The recorded data in Table 7 cleared that yeasts organisms were detected at incidences of 70, 30, 30, 55,45 and $35 \%$ in the examined samples of fermented milk, respectively. The mean value of yeasts count was $7.87 \times 10^{4} \pm 6.89 \times 10^{4} ; 5.83 \times 10^{3} \pm$ $3.68 \times 10^{3} ; 2.16 \times 10^{3} \pm 6.54 \times 10^{2} ; 1.26 \times 10^{4} \pm 3.55 \times 10^{3}$; $9.11 \times 10^{3} \pm 3.82 \times 10^{3}$ and $1.28 \times 10^{3} \pm 0.79 \times 10^{2} \mathrm{CFU} / \mathrm{g}$, respectively. The recorded results were in agreement with Adebesin et al. (2001) who showed that yeasts counts were ranged from $1.0 \times 10^{4}$ to $5.3 \times 10^{4}$ $\mathrm{CFU} / \mathrm{ml}$ in locally manufactured fermented milk in Nigeria.

According to the limits proposed by the Egyptian standards (yeasts must not be detected), it was noticed that 70,30 and $30 \%$ of the examined samples of plain, stirred and flavored yoghurt, respectively failed to comply with the limits (Table 9). Also, it was noticed that 55,45 and $35 \%$ of the examined samples of baladi rayeb, sterilized rayeb and Labnah, respectively were failed to comply with the standard limits (Table 10).

\subsection{Molds count:}

The examination for molds is a matter of interest because the mycotoxigenic fungi were able to grow at refrigeration temperature to numbers, which can result in an infection (Potter and Hotchkiss, 1995). Presence of molds in milk and dairy products are undesirable even when found in few numbers as they resulting in objectionable changes that render the products of inferior quality (Abdel Hameed, 2011). Molds and yeasts growing in yoghurt utilized some of the acid and produce a corresponding decrease in the acidity, which may favor the growth of putrefactive bacteria (Oyeleke, 2009).

The presented data in Table 8 cleared that molds were detected at an incidence of 55, 25, 35, 70, 20 and 100 $\%$ in the examined concering samples, respectively. The mean value of molds count was $5.88 \times 10^{4} \pm$ $4.06 \times 10^{4} ; 2.60 \times 10^{3} \pm 1.12 \times 10^{3} ; 7.57 \times 10^{3} \pm 4.72 \times 10^{3}$; $2.92 \times 10^{3} \pm 4.38 \times 10^{2} ; \quad 3.00 \times 10^{3} \pm 1.41 \times 10^{3}$ and
$2.75 \times 10^{3} \pm 1.12 \times 10^{3} \mathrm{CFU} / \mathrm{g}$, respectively. According to the limits proposed by the Egyptian standards (molds count must be $<10 \mathrm{CFU} / \mathrm{g}$ ), it was noticed that 55,25 and $35 \%$ of the examined samples of plain, stirred and flavored yoghurt, respectively failed to comply with the limits (Table 9), and, 70, 20 and 100 $\%$ of the examined samples of baladi rayeb, sterilized rayeb and Labnah, respectively failed to comply with the limits (Table 10). The obtained results were in agreement with Shawer (1997) who recorded that mean value of molds count was $3 \times 10^{3} \pm 1.35 \times 10^{3}$ $\mathrm{CFU} / \mathrm{g}$.

According to the obtained results of the current study, it could be concluded that the majority of the investigated fermented dairy products that randomly collected from local markets in Alexandria city were contaminated, at a different degrees, with coliforms, Staph. aureus, Enterococci, yeasts and molds giving an indication of poor sanitary measures adopted during manufacturing, storage, handling and distribution of these products. It was concluded and observed that the baladi rayeb and labnah had lower quality than the other examined fermented dairy products. For this reason, increased emphasis should be placed on the microbiology of milk and dairy products. This analysis is critical for the assessment of quality and safety confirmation with standards, specification and regularity compliance.

The application of Hazard Analysis and Critical Control Point (HACCP) as advocated by the WHO should be applied to a wide range of fermented foods in addition to other measures such as use of starter cultures, legislation and educating handlers who prepare such food.

\section{REFERENCES}

Abdel All, A.A. and Dardir, H.A. (2009): Hygienic quality of local traditional fermented skimmed milk (Laban Rayb) sold in Egypt. World Journal of Dairy and Food Sciences, 4(2): 205209.

Abdel Hameed and Karima, G. (2011): Evaluation of chemical and microbiological quality of raw goat milk in Qena province. Assiut Vet. Med. J., 57 (129): 131-144.

Adebesin, A.A.; Amusa, N.A. and Fagade, S.O. (2001): Microbiological quality of locally fermented milk (nono) and fermented milkcereal mixture (fura da nono) drink in Bauchi, a Nigerian city. The Journal of Food Technology in Africa, 6 (3): 87-89

AOAC (Association of Official Analytical Chemists), (1990): Official Methods of Analysis. 15 ${ }^{\text {th }}$ ed., Association of Analytical Chemists, Washington, DC, USA.

APHA (American Public Health Association), (1985): Standard Methods for the Examination of 
Dairy Products. $15^{\text {th }}$ ed., American public Health Association, New York.

Baily, W.R. and Scott, E.G. (1998): Diagnostic Microbiology: A textbook for the isolation and Identification of pathogenic microorganisms. The C.V. Mosby Company Saint Louis.

Baird-Parker, A.C. (1962): An improved diagnostic and selective medium for isolation of coagulase positive Staphylococci. J. Appl. Bacteriol., 25: 12-19

Balasubramanyam, B.V. and Kulkarnis, N. (1991): Standardization of manufacture of high fat yoghurt with natural fruit pulp. J. Food Sci. Techno., 28 (6): 389-390.

Brightwell, G.; Boerema, J.; Mills, J.; Mowat, E. and Pulford, D. (2006): Evaluation of molecular methods to determine enterotoxigenic status and molecular genotype of bovine, ovine, human and food isolates of Staphylococcus. aureus. Inter. J. Food Microbiol., 107: 192201.

Deibel, R.H. and Hartman, P.A. (1982): The Enterococci. In: Compendium of Methods for the Microbiological Examination of Foods, 2 ed., Speck, M.L. (ed.). American Public Health Association, Washington, D.C, USA.

Egyptian Standards (1999): Milk and products. Yoghurt, Egyptian organization for Standardization and Quality Control, ES: 1650 $-1999$.

El-Leboudy, Ahlam, A.; Amer, A.A.; El-Gaml, A.M. and Shahin, H.F. (2015): Sanitary evaluation of curd dairy products. Alexandria Journal of Veterinary Sciences, 45: 51-56.

El-Malt, Laila, M.; Hameed, Karima, A. and Mohammed, A.S. (2013): Microbiological evaluation of yoghurt products in Qena city, Egypt. Veterinary World, 6(7): 400-404.

EOSQC (2005): Egyptian Organization for Standardization and Quality Control for chicken carcasses, No. 1090.

Fleet, G.H. (1990): Yeasts in dairy products. J. Appl. Bacteriol., 68: 99-211.

Food and Drug Administration (FDA) (2002): Bacteriological Analytical Manual. 9th Ed., AOAC International, Arlington, VA, USA.

Khan, K.R.; Khan, S.U.; Anwar, M.A. and Bhadar, F.S. (2008): Physical and chemical quality appraisal of commercial yoghurt brands sold at Lahore. Asian Research Publishing Network journal of Agricultural and Biological Science, 3 (3): $14-21$.
McKinley, M.C. (2005): The nutrition and health benefits of yoghurt. Int. J. Dairy Technol., 58: $1-12$.

Oyeleke, S.B. (2009): Microbial assessment of some commercially prepared yogurt retailed in Minna, Niger State. Afr. J. Microbiol. Res. 3: 245- 248.

Pazakova, J.; Turek, P. and Laciakova, A. (1997): The survival of $S$. aureus during the fermentation and storage of yoghurt. J. Appl. Micobiol, 82: 659-662.

Pitt, J.I. and Hocking, A.D. (2009): Fungi and Food Spoilage. Springer Science Business Media, New York Library of Congress.

Potter, N.F. and Hotchkiss, J.H. (1995): Food Science. $5^{\text {th }}$ ed., KY. Chapman and Hall (Routledge), Florence, quality, riboflavin and niacin of plain and fruit yoghurt. Indian $\mathrm{J}$. Dairy Sci., 39(4): 404- 409.

Samet-Bali, O.; Felfoul, I.; Lajnaf, R.; Attia, H. and Ayadi, M.A. (2016): Hygienic quality of" Rayeb", a traditional Tunisian fermented cow's milk. J. Inter. Food Res., 23(1), 366-369.

SAS (2014): Statistical user's Guide. Statistical analysis system. INT., Cary, NC. USA.

Shawer, Hadeer, I.A. (1997): Fungal contamination of some dairy products M.V.Sc. Thesis, Fac. Vet. Med., Alexandria. Univ.

Somer, V.F. and Kilic, G.B. (2012): Microbiological, physicochemical properties and biogenic amine contents of the strained yoghurts from Turkish local markets. Afr. J. Biotechnol., 11 (78), 14338.

Tamine, A.Y. and Robinson, R.K. (2007): Yoghurt: Science and Technology. $3^{\text {rd }}$ ed. Cambridge, Woodhead Publishing Limited p: 808.

Thapa, T.B. (2000): Small-scale milk processing technologies: Other milk products. An Electronic Conference, Food and Agriculture Organization of the United Nation. Rome, Italy,

Todaro, A.; Adly, F.A. and Omar, Ola A.H. (2013): History, processing and quality enhancement of traditional Egyptian kariesh cheese. J. Food Science and Technology, 1: 1-6.

Uzeh, R.E.; Ohenhen, R.E. and Rojugbokan, A.K. (2006): Microbiological and nutritional qualities of dairy products: Nono and Wara. Nature and science, 4(3): 37-40.

Yabaya, A. and Idris, A. (2012): Bacteriological quality assessment of some yoghurt brands sold in Kaduna Metropolis. J. of Research in National Development, 10(2), 35-39. 


\section{تقييم بعض الألبان المتخمرة المباعة في مدينة الإسكندرية \\ أحلام اللبودى ، عصرو عامر ، مارية الاتصارى ، محدد سعيل الاسيوطى ، مروة رمضان أحميلة}

Email: mido_15158@hotmail.com_Assiut University web-site: www.aun.edu.eg

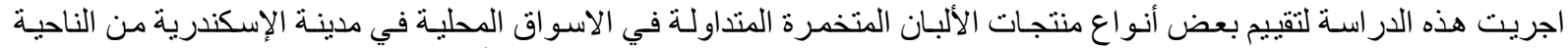

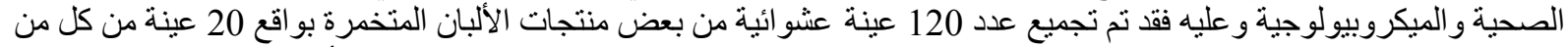

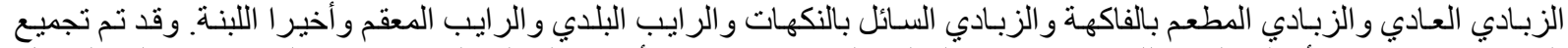

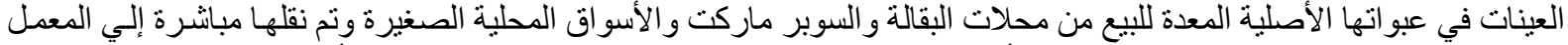

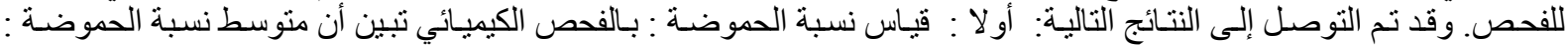

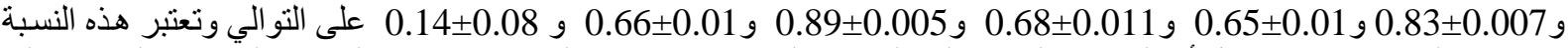

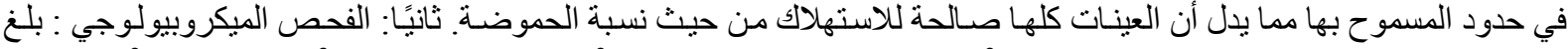

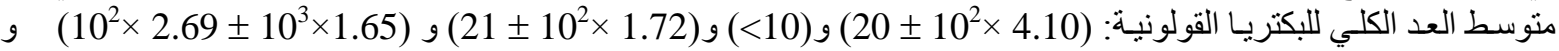

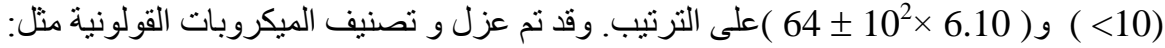

Citrobacter freundii, E.coli, Enterobacter aerogenes, Enterobacter cloacae, Proteus vulgaris, Edwardsiella tarda and Klebsiella pneumoniae

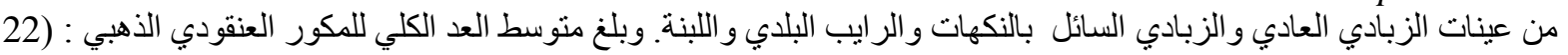

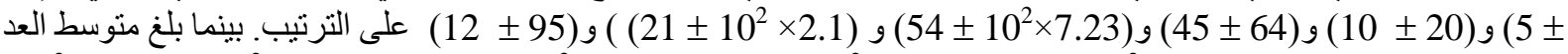

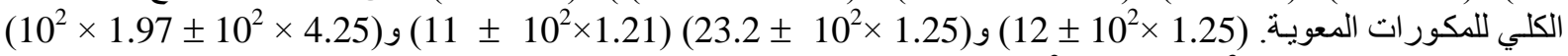

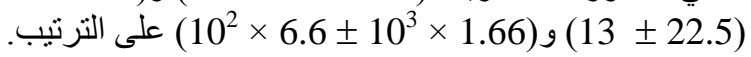

كذللك أظهر الفحص الميكروبيولوجي أيضا نو اجد الخمائر و الفطريات بنسب متنوعة في جميع المنتجات المختبرة . حيث بلغ منوسط

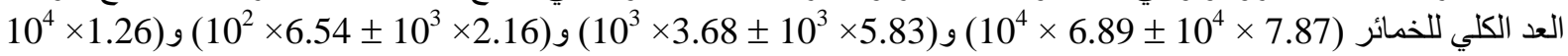
1 للفطريات $\left(10^{2}\right.$

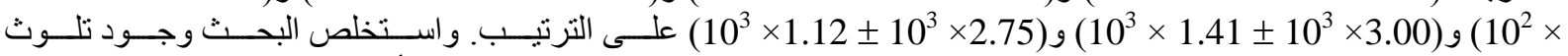

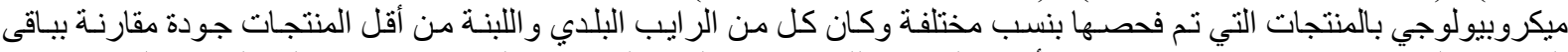

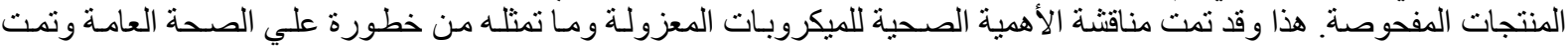
التوصية بضرورة مر اعاة الشروط الصحية للحصول علي منتج نهائي ذو جودة عالية وآمن للمستهلكيك.

الكلمات الكاشفة : منتجات الألبان المتخمرة ، التقييم الصحي ، التقييم الميكروبيولوجي. 